\title{
SOVEREIGN RISK AND THE BANK LENDING CHANNEL IN \\ EUROPE
}

\begin{abstract}
The main purpose of this article is to analyze how sovereign risk influences the loan supply reaction of banks to monetary policy through the bank lending channel. Additionally, we aim to test whether this reaction differs in easy and tight monetary regimes. Using a sample of 3,125 banks from the euro zone between 1999 and 2012, we find that sovereign risk plays an important role in determining loan supply from banks during tight monetary regimes. Banks in higher sovereign risk countries reduce lending more during tight regimes. However, we find little evidence to support any relationship between sovereign risk and loan supply reaction to monetary policy expansions. These results are very interesting for the way monetary policy is conducted in Europe. Banking union, banking system strength, and the budget control of governments would be necessary measures to reduce the heterogeneous transmission of the monetary policy in the euro zone.
\end{abstract}

Key words: Monetary policy; Bank lending channel; Sovereign risk.

JEL classification: E44, E52, G21. 


\section{SOVEREIGN RISK AND THE BANK LENDING CHANNEL IN \\ EUROPE}

\section{Introduction}

The financial crisis that started in 2008 has highlighted the importance of financial intermediaries in the monetary policy transmission process. The role played by these intermediaries as loan suppliers is essential to understand how monetary policy affects the economy. In the economic literature and among practitioners, there has been a renewed interest in analyzing the bank lending channel as a monetary policy transmission mechanism ${ }^{1}$. According to this approach, monetary policy impulses lead to a shift in the loan supply of banks because these impulses affect the access of banks to loanable funds (Bernanke and Blinder, 1988).

In this framework, it has been argued that the reaction of loans supply to monetary shocks varies depending on bank-specific characteristics (Kashyap and Stein, 1995a, 1995b, 2000; Peek and Rosengren, 1995; Kishan and Opiela, 2000; 2006; Altunbas et al., 2010). Smaller, less liquid, more poorly capitalized and higher-risk banks are less able to insulate their lending from tight monetary policies because of their limited ability to raise uninsured sources of funds. Additionally, monetary policy is less effective in high concentrated banking markets, mainly because these markets have bigger banks with better access to funding (Olivero et al., 2011; Adams and Amel, 2005; 2011).

Since the onset of the financial crisis of 2008, there has been a growing concern about the impact that sovereign risk could have on financial intermediaries, their balance sheets, and

\footnotetext{
${ }^{1}$ See, among others, Opiela (2008), Isakova (2008), Matousek and Sarantis (2009), Brissimis and Delis (2009), Altunbas et al. (2009; 2010), Gambacorta and Marques-Ibanez (2011), Disyatat (2011), Said (2013).
} 
their ability to grant credit. The financial crisis caused a sharp deterioration in public finances of many developed countries, raising investor concerns about sovereign risk. This is especially relevant in the euro area, where, before the crisis, in all countries sovereign debt had a risk-free status, which has been lost in several countries during the recent financial turmoil. Greater sovereign risk has pushed up the cost and reduced the availability of some euro area banks' funding, leading to a sharp price differentiation across countries.

These funding problems will influence the supply of credit from banks located in higher sovereign risk countries, thereby impacting on the bank lending channel as a monetary policy transmission mechanism. Consequently, monetary policy decisions adopted by the European Central Bank (ECB) will be transmitted in a heterogeneous way across countries. This fragmentation makes it increasingly difficult to conduct a single monetary policy in the euro area. Despite the negative repercussions of this effect, very little research has been done on this issue. Some papers analyze the effects of a crisis on the bank lending channel (Beltratti and Stulz, 2009; Gambacorta and Mistrulli, 2004; Altunbas et al., 2009; Gambacorta and MarquesIbanez; 2011; Brei, et al., 2013). They focus their attention on capital, liquidity, risk, securitization or rescue packages, but they do not study how sovereign risk influences bank credit supply reaction to monetary policy changes. Adelino and Ferreira (2014) analyze the impact that sovereign rating downgrades have on bank lending supply to the private sector. They find that banks with ratings bounded by sovereign rating reduce lending more than similar banks with lower rating after sovereign downgrades. However, they do not consider monetary policy, so they do not study how bank credit supply reaction to monetary policy is affected by sovereign risk.

In this regard, the main contribution of this paper is to quantify the effect that sovereign risk has on the loan supply reaction of banks to monetary policy changes. Moreover, we analyze this effect during periods of tightening and expansionary monetary policy to capture the 
differences between these policies. To do so, we include linear and squared interaction terms between the variables that measure the monetary policy changes and sovereign risk, both of which are continuous. On the one hand, the interaction between continuous variables allows us to analyze how loan supply reaction to monetary policy varies according to sovereign risk. On the other hand, the introduction of squared variables allows us to capture the differences between restrictive and expansionary monetary policies. This approach has been used to assess differences between groups or periods in other areas of financial research, e.g., market timing in mutual funds (Treynor and Mazuy, 1966), but has not been used to analyze the bank lending channel.

Our empirical analysis comprises a sample of 3,125 banks from twelve euro zone countries (the original eleven countries plus Greece) over the period 1999-2012. The selection of these countries allows analysis of the effect of sovereign risk on the bank lending channel, avoiding the bias caused by different monetary policies. In addition, our dataset comprises the entire period during which the European Central Bank carried out the single monetary policy in the euro zone, including the whole financial crisis.

The analysis is performed using the System-GMM methodology for panel data. This methodology allows controlling both unobservable heterogeneity and the problems of endogeneity between monetary policy and characteristics of banks through the use of instruments. This methodology yields consistent and unbiased estimates of the relationships between the macroeconomic variables, bank-specific characteristics and bank lending.

We find that banks in higher sovereign risk countries reduce their lending more during a tightening monetary policy than do banks in lower sovereign risk countries. Banks more affected by sovereign risk tensions tend to face greater funding costs and keep high levels of precautionary liquidity, which is why they are more affected by monetary policy contractions. Our results also show that there is not enough evidence to support a relationship between 
sovereign risk and loan supply reaction to monetary policy expansions. The reason for this result might be that after the beginning of the financial crisis in 2008 , the access of banks to funding is limited and expensive in most euro zone countries, which outweighs the benefits of the monetary expansion conducted by the European Central Bank at the time. These results are very interesting for the way monetary policy is conducted in Europe. Banking union, banking system strength, and governments' budget control would be necessary measures to reduce the heterogeneous transmission of the monetary policy in the euro area.

The remainder of the article is structured as follows: Section 2 reviews the previous literature. Section 3 focuses on the empirical analysis and the discussion of the results. Section 4 presents the conclusions, followed by the bibliography.

\section{Literature review}

\subsection{The bank lending channel (BLC)}

Monetary policy exerts its influence through several channels or mechanisms, which include the interest rate effects, exchange rate effects, other asset price effects, and the credit channel (Mishkin, 1995). The credit channel includes two basic sub-channels that arise owing to financial frictions in the credit markets (Bernanke and Blinder, 1988): the borrower net worth channel (BNWC) (also known as the balance sheet channel), and the bank lending channel (BLC). The first sub-channel, the BNWC, operates through the net worth of firms. A restrictive monetary policy deteriorates the balance sheets of borrowers, which increases their debt services and reduces the collateral value of their assets (Bernanke and Gertler, 1995). Lower net worth of firms implies having less collateral for their loans. Thus, lenders are induced to require higher compensations. If borrowers are unable to pay the higher compensations, their access to credit will be reduced. As a result, they will decline their investment activities. 
The second sub-channel, the BLC, which is the main focus of this paper, highlights the special role played by banks in the financial systems and amplifies the conventional interest rate channel (Bernanke and Gertler, 1995). According to the BLC approach, changes in monetary policy lead to a shift in the credit extended by banks. In this regard, monetary policy impulses affect bank deposits and, consequently, their access to loanable funds (Bernanke and Blinder, 1988). In this context, a tight monetary policy causes a decline in the amount of bank deposits, which curtails lending supply. This association between monetary policy and deposits can be explained by two mechanisms. Firstly, monetary policy changes are implemented via open market operations that modify the amount of bank reserves. A tightening monetary policy increases the level of required reserves that banks must hold in the central bank, which limits the issuance of bank deposits to the availability of bank reserves (Kashyap and Stein, 1995a; Walsh, 2003). Secondly, policy actions alter the yields of deposits relative to other assets, thereby influencing households' willingness to hold them (Kishan and Opiela, 2000; Ehrmann et al., 2003) ${ }^{2}$.

In the last few years, Bernanke (2007) and Disyatat (2011) have suggested other mechanism for the BLC owing to the increased use of market-based funding. In this regard, a restrictive monetary policy increases banks' external finance premium, subjecting them to higher cost of funds, which are then passed on lending. This new mechanism proposes a BLC that works through the impact of monetary policy on the sensitivity of banks' external funding costs. Thus, not only do monetary policy impulses affect bank deposits, but also the marketbased financing of banks.

\footnotetext{
${ }^{2}$ Three conditions are necessary for the BLC to be effective (Bernanke and Blinder, 1988). First, firms must be dependent on bank loans. Second, central banks must be able to affect lending supply by modifying the level of required reserves. To this regard, during monetary contractions banks must not be able to offset the decline in deposits by funds from other sources. However, according to Romer and Romer (1990) banks can easily overcome the drains in deposits by simply raising non-deposit funds, such as CDS or bonds, which weakens the BLC. Third, there must be imperfections in the aggregate price level adjustment to prevent any monetary policy shock from being neutral.
} 
To sum up, the underlying mechanism of the BLC is one in which a tight monetary policy is followed by a decline in the amount of loanable funds via deposits and/or an increase in banks' external finance premium. As a result, this fact leads to a reduction in loans supply.

A great number of studies have analyzed the response of lending to shifts in monetary policy, depending on bank-specific characteristics or their balance sheet strengths. This is because a tight monetary policy causes a drop in deposits, which forces banks to substitute towards uninsured sources of funds. Raising uninsured funds is more difficult for banks with weak balance sheets, so their lending behavior is more sensitive to monetary shocks (Kishan and Opiela, 2006). Moreover, the external finance premium of banks is very sensitive to their financial health. Thus, during a tight monetary policy, banks with weaker balance sheets experience a greater variability in their external finance premium and, consequently, their loan supply is more adversely affected (Disyatat, 2011).

In this regard, the balance sheet strength of banks has been measured in terms of size, liquidity, capitalization, and credit risk. Smaller banks are more affected by a monetary contraction, since they tend to have simpler capital structures and cannot access to alternative sources of funds such as cash or securities (Kashyap and Stein, 1995a, 1995b, 2000; Kishan and Opiela, 2000, 2006). Less liquid banks cannot quickly and with no cost compensate the loss of deposits in a tight regime, so they are more responsive to monetary policy (Kashyap and Stein, 2000; De Bondt, 1999; Gambacorta, 2005; Matousek and Sarantis, 2009). Poorly capitalized banks are perceived as more risky by market participants, so it is more expensive for them to access to external finance. In addition, low capitalized banks have more difficulties in obtaining finance in the capital markets to protect their loan portfolio. As a result, they experience a greater decrease in lending after a monetary tightening (Peek and Rosengren, 1995; Kishan and Opiela, 2000; 2006; Altunbas et al., 2002). Banks with higher credit risk are less able to insulate their loan supply from monetary changes, because they have more difficulties in raising new 
funds (Altunbas et al., 2010; Bogoev, 2010). Apart from bank-specific characteristics the existing literature has also analyzed banking concentration. In this regard, more concentrated banking markets are less sensitive to monetary shocks, because they have bigger banks with better funding conditions (Olivero et al., 2011; Adams and Amel, 2005, 2011).

Finally, the onset of the financial crisis in 2008 has increased the interest on the relationship between interest rates and bank risk taking. In this regard, the monetary policy's risk taken channel proposes that not only do changes in interest rates affect the quantity but also the quality of bank credit. Monetary policy expansions tent to induce banks to engage in more risky activities and credit standards are loosened when interest rates are low (Jimenez et al., 2008; Ioannidou et al., 2009; Maddaloni and Peydro, 2011; Paligorova and Santos, 2012). In this regard, Dell'Ariccia et al. (2013) find that increases in short term monetary policy interest rates gives rise to reductions in risk taken by banks. However, this effect is less intense for banks with low capital and during crisis.

\subsection{Sovereign risk and the bank lending channel}

The financial crisis raised investor concerns about sovereign risk in several European countries. Greater sovereign risk has pushed up the funding cost of some euro area banks and has impaired their access to finance (CGFS, 2011; Vause and von Peter, 2011; Caruana and Avdjiev, 2012). This context has clearly shown that banks' funding cost and availability depend to an important extent on their home country sovereign risk.

In this regard, there are several mechanisms by which sovereign risk impacts on banks' funding access and its cost. Firstly, banks usually hold domestic government debt, which enables them to hold less regulatory capital against that debt. This is because government securities have always been considered risk free (Barth et al., 2012). Higher sovereign risk leads to losses on banks' holdings of sovereign debt. This deteriorates their balance sheet and 
increases their risk, making obtaining funding more difficult and expensive (Trichet, 2010; Alter and Schüler, 2012). This is very important in Europe, since banks in the euro area are greatly exposed to their home country debt (Bruyckere et al., 2012; Breton et al., 2012).

Secondly, greater sovereign risk reduces the value of collateral that banks can use to raise wholesale funding and obtain liquidity from the central bank (Trichet, 2010; Davies and Ng, 2011; Allen and Moessner, 2012).

Thirdly, sovereign rating downgrades are often followed by downgrades in domestic banks rating, which increase the banks' funding costs and restrict their market access (CGFS, 2011). When the sovereign has not a triple A rating or closer, which is the high end of the scale, ratings for banks from that country will tend to suffer, regardless of their financial strength. This is because the sovereign rating usually acts as a ceiling for the rating of banks (Peter and Grandes, 2005; Borensztein et al., 2006). This correlation between changes in sovereign ratings and changes in ratings of banks is significantly higher for rating downgrades than for upgrades (Ferri et al., 2001).

Fourthly, sovereign risk deterioration reduces the benefits that certain banks obtain from implicit and explicit government guarantees. Systemic banks have always had an implicit government guarantee due to the adverse effects such banks' bankruptcy would have on the economy. These additional guarantees have always lowered their funding costs (Grande et al., 2011; Correa et al., 2012). Due to sovereign risk tensions, the value of these guarantees has been reduced in weaker euro area countries (Schich and Lindh, 2012; Gray and Malone, 2012).

Finally, investors' risk aversion and uncertainty about the quality of banks' balance sheets have also contributed to the rising funding costs for those banks located in high sovereign risk countries. In this regard, the European Central Bank (2012) highlights that during the crisis the cost of funds has clearly depended on the banks' country of origin, leading to a sharp price differentiation across countries. 
Several studies have analyzed how sovereign risk affects the funding costs and lending of banks. Bofondi et al. (2013) examine how the sovereign debt crisis in Italy, by increasing the funding costs of banks, has been transmitted to bank lending. They find that Italian banks have reduced their loan supply more than foreign competitors during the sovereign crisis. Other studies focused on the Italian banks report similar results (Albertazzi et al., 2012; Zoli, 2013). At the same time, Popov and Van Horen (2013) find that a deterioration of foreign sovereign debt held by credit entities leads to an increase in the funding costs of banks, declining loan supply. Recently Ciccarelli et al. (2013), by using aggregate data for 12 euro area countries, have reported that the impact of monetary shocks on gross domestic product (GDP) growth is amplified through the credit channel in countries under sovereign stress.

All in all, funding costs are greater for banks in countries with higher sovereign risk, and this will pass on to their customers in the supply and the price of credit offered to them.

Regarding the impact that sovereign risk has on the loan supply reaction of banks to monetary policy changes, a tight monetary policy leads to a credit reduction, because it affects the access of banks to loanable funds (either deposits or market-based funding) and their cost. This credit reduction will be more acute for banks that operate in higher sovereign countries, because such banks face greater funding costs and financial restrictions ${ }^{3}$. However, the effect of a monetary policy expansion on banks in high sovereign risk countries is not clear. On the one hand, an easy monetary policy alleviates financial frictions and increases the assets banks have available to lend out (Gibson, 1997; Boivin et al., 2010). Moreover, low rates decrease the riskiness of the overall loan portfolios of banks, which induce them to increase their loans and

\footnotetext{
${ }^{3}$ When sovereign risk is very high, depositors tend to demand greater compensations or even they may reject to deposit their funds. To this regard, after the onset of the sovereign debt crisis, there have been massive withdrawals of deposits from European banks in countries more affected by sovereign tensions. In addition, these banks have had more difficulty raising new deposits (CGFS, 2011). Additionally, when sovereign risk is very high, the access of banks to external funding depends more on their sovereign rating rather than on their individual rating class, which increases their financing cost. According to the ECB (2012), market-based financing has been more difficult for banks in countries strongly affected by the sovereign debt crisis.
} 
loosen their credit standards (Jimenez et al., 2008; Ioannidou, et al., 2009; Maddaloni and Peydro, 2011; Paligorova and Santos, 2012). On the other hand, banks in high sovereign risk countries might be less benefited from monetary expansions because their access to external funds is more limited and expensive. Consequently, these banks might be less able to fully transmit the expansionary effects on lending of an easy monetary policy.

Sovereign risk can also affect the loan supply reaction of banks to monetary policy changes due to precautionary liquidity. During a monetary policy restriction banks more affected by sovereign risk tensions will keep high levels of precautionary liquidity because of their finance uncertainties (Freixas et al., 1999; Zawadowski, 2011; Acharya et al., 2011; Brunnermeier and Oehmke, 2012) and their high rollover risk arising from their high funding cost (Caceres et al., 2010; Unsal and Caceres, 2011). This high precautionary liquidity will give rise to a big reduction in their lending supply. However, during monetary policy expansions banks in high sovereign countries do not have to hoard high levels of precautionary liquidity because interest reduction might alleviate their financial problems.

To sum up, a tight monetary policy will lead to a more acute credit reduction for banks that operate in higher sovereign risk countries. However, during monetary policy expansions, it is not clear if banks in high sovereign risk countries will expand their loan supply less than banks in low sovereign risk countries.

\section{Empirical analysis}

\subsection{Selection of the sample}

We use a sample of credit institutions (banks, savings banks, and cooperative banks) from twelve euro zone countries (the original eleven countries plus Greece) ${ }^{4}$ between 1999 and

\footnotetext{
${ }^{4}$ Austria, Belgium, Finland, France, Germany, Greece, Ireland, Italy, Luxembourg, Netherlands, Portugal, and Spain.
} 
2012. The selection of these countries allows analyzing the effect that sovereign risk has on monetary policy, avoiding the bias caused by different monetary policies. In addition, the years selected allows to analyze the whole financial crisis in the empirical specification. Following Favero et al. (1999), Arena et al. (2007) and Olivero et al. (2011), we remove the banks in the following cases: 1) banks with negative values of assets, loans, deposits, interest income, and expenses; 2) banks with growth rates of loans and/or deposits greater than $300 \%$; 3) banks with loans 100 times greater than deposits.

Table 1 shows the number of institutions and observations from each country and the temporary distribution of the sample. We use a panel of credit institutions with data available for a minimum of four consecutive years between 1999 and 2012. This condition is essential in order to test for second-order serial correlation, which is performed to ensure the robustness of the estimates made by System-GMM (Arellano and Bond, 1991). The financial information on each institution comes from the BankScope database. The macroeconomic information comes from the World Development Indicators database of the World Bank, OECD statistics, the European Central Bank, and EuroStat.

[Insert table 1]

\subsection{Econometric model and data}

To test the hypotheses, we propose the following model based on the approach of Kashyap and Stein (1995a): 


$$
\begin{aligned}
& \Delta \ln (\text { loans })_{i, t}=\alpha_{0}+\alpha_{1} \Delta \ln (\text { loans })_{i, t-1}+\sum_{j=0}^{1} \delta_{j} \Delta \ln (\mathrm{GDP})_{m, t-j}+\sum_{j=0}^{1} \beta_{j} \Delta \mathrm{i}_{m, t-j}+ \\
& \rho_{1} S I Z E_{i, t-1}+\rho_{2} L I Q_{i, t-1}+\rho_{3} C A P_{i, t-1}+\rho_{4} L L P_{i, t-1}+\sum_{j=0}^{1} \tau_{j} \Delta \mathrm{i}_{m, t-j} * S I Z E_{i, t-1}+ \\
& \sum_{j=0}^{1} \theta_{j} \Delta \mathrm{i}_{m, t-j} * L I Q_{i, t-1}+\sum_{j=0}^{1} \mu_{j} \Delta \mathrm{i}_{m, t-j} * C A P_{i, t-1}+\sum_{j=0}^{1} \varphi_{j} \Delta \mathrm{i}_{m, t-j} * L L P_{i, t-1}+ \\
& \rho_{5} M C_{m, t}+\sum_{j=0}^{1} \omega_{j} \Delta \mathrm{i}_{m, t-j} * M C_{m, t}+\rho_{6} S R_{m, t}+\sum_{j=0}^{1} \gamma_{j} \Delta \mathrm{i}_{m, t-j} * S R_{m, t}+\sum_{j=0}^{1} \epsilon_{j}\left(\Delta \mathrm{i}_{m, t-j} *\right. \\
& \left.S R_{m, t}\right)^{2}+\sum_{t=1}^{13} \pi_{t} \text { Year }_{t}+\sum_{m=1}^{11} \vartheta_{m} \text { Country }_{m}+\varepsilon_{i, t}
\end{aligned}
$$

The dependent variable, $\Delta \ln (\text { Loans })_{i, t}$, measures the growth rate in loan supply from bank $i$ in year $t$ relative to year $t$-1. This variable has been widely used in the bank lending channel literature (Ehrmann et al., 2003; Gambacorta, 2005; Jimborean, 2009; Olivero et al., 2011; Gambacorta and Marques-Ibanez, 2011). As in previous studies, we include loan growth lagged one year $\left(\Delta \ln (\text { Loans })_{i, t-1}\right)$ as an independent variable to capture the persistence of the dependent variable.

The variable $\Delta \ln (G D P)$ represents the nominal GDP growth rate (Altunbas et al., 2010). This variable controls for demand shocks. Better economic conditions increase the number of profitable projects, which impulses the demand for credit (Kashyap et al., 1993). Thus, this variable captures the cyclical movements and serves to isolate the monetary policy component of interest rates. Most studies have found that GDP growth influences positively the supply of credit (Jimborean, 2009; Wu et al., 2011). Consequently, we expect a positive relationship between this variable and the growth in lending.

The monetary policy indicator $\Delta i$ is measured by the change in the short-term money market rate (de Bondt, 1999; Ehrmann et al., 2003; Altunbas et al., 2010; Olivero et al., 2011). We use the current and one-year lagged monetary policy indicators $\left(\Delta i_{m, t}\right.$ and $\left.\Delta i_{m, t-1}\right)$, because banks may not respond immediately to monetary policy decisions. As in previous studies, we expect that an increase in short-term money market rate gives rise to a reduction in the growth of bank lending. 
We introduce in model (1) four bank-specific characteristics ${ }^{5}$ :

SIZE is defined as the log of total assets. Usually, large banks enjoy higher loan growth rates, so we expect that this variable has a positive sign (Kashyap and Stein, 1995a, 1995b, 2000).

$L I Q$ is the ratio of securities and cash due from banks to total assets. More liquid banks usually experience higher loan growth rates, so we expect that this variable has a positive sign (de Bondt, 1999; Kashyap and Stein, 2000).

$C A P$ is the ratio of total equity to total assets. Higher capitalized banks tend to enjoy higher lending volumes, so we expect that this variable has a positive sign (Kishan and Opiela, 2000, 2006; Hosono, 2006).

$L L P$ is the ratio of loan-loss-provisions to total loans, and is used to capture banks' credit risk. Banks with higher credit risk have lower credit growth rates, so we expect that this variable has a negative sign (Altunbas et al., 2010; Bogoev, 2010; Wu et al., 2011).

We include interaction terms between monetary policy variables $\left(\Delta i_{m, t}\right.$ and $\left.\Delta i_{m, t-1}\right)$ and the bank-specific characteristics variables (SIZE, LIQ, CAP, and $L L P)$ to capture the effect that these characteristics has on monetary policy changes.

Firstly, we introduce the interaction variables between SIZE and monetary policy indicators $\left(\Delta i_{m, t}\right.$ and $\left.\Delta i_{m, t-1}\right)$. Several studies have found a positive relationship between these interaction variables and the growth rate of loans, because smaller banks tend to be more sensitive to monetary policy restrictions than bigger banks (Kashyap and Stein, 1995a, 1995b, 2000; Kishan and Opiela, 2000; Kakes and Sturm, 2002). However, other studies have obtained

\footnotetext{
${ }^{5}$ As in most previous studies we use these four bank-specific characteristics lagged one year to avoid endogeneity bias (Kashyap and Stein, 1995a, 1995b, 2000; Ehrmann et al., 2003).
} 
a non-significant or even a negative relationship (Steudler and Zurlinden, 1998; Angeloni et al., 2003; Gambacorta, 2005).

Secondly, we introduce the interaction variables between $L I Q$ and monetary policy indicators $\left(\Delta i_{m, t}\right.$ and $\left.\Delta i_{m, t-1}\right)$. Several works have reported that liquid banks are less sensitive to monetary shocks, because such banks usually find it easier to avoid cutting loans following a tightening monetary policy (Kashyap and Stein, 2000; Ehrmann et al., 2003; Gambacorta, 2005). On the contrary, some studies have found the opposite result, which can be due to the existence of a structural excess of liquidity (Matousek and Sarantis, 2009; Jimborean, 2009; Bogoev, 2010).

Thirdly, we introduce the interaction variables between $C A P$ and monetary policy indicators $\left(\Delta i_{m, t}\right.$ and $\left.\Delta i_{m, t-1}\right)$. Several studies have found that poorly capitalized banks have more difficulties in accessing to non-deposit financing, so they reduce lending more than wellcapitalized banks during monetary policy tights (Peek and Rosengren, 1995; Kishan and Opiela, 2000; 2006; Altunbas et al., 2002; Hosono, 2006).

Finally, we introduce the interaction variables between $L L P$ and monetary policy indicators $\left(\Delta i_{m, t}\right.$ and $\left.\Delta i_{m, t-1}\right)$. Several works have found that higher-risk banks reduce lending more than banks with low risk (Altunbas et al., 2010; Bogoev, 2010; Wu et al., 2011).

We use continuous variables to create the previous interaction terms. To interpret these interaction terms properly, the four bank-specific variables (SIZE, LIQ, CAP, and LLP) are normalized with respect to their mean across all banks in the sample ${ }^{6}$.

$$
S I Z E_{i t}=\log A_{i t}-\frac{\sum_{i=1}^{N} \log A_{i t}}{N_{t}}
$$

\footnotetext{
${ }^{6}$ Many previous studies have followed the same approach (Ehrmann et al., 2003; Gambacorta, 2005; PruteanuPodpiera, 2007; Jimborean, 2009).
} 


$$
\begin{gathered}
L I Q_{i t}=\frac{L_{i t}}{A_{i t}}-\frac{\sum_{t=1}^{T}\left(\sum_{i=1}^{N}\left(L_{i t} / A_{i t}\right) / N_{t}\right)}{T} \\
C A P_{i t}=\frac{E_{i t}}{A_{i t}}-\frac{\sum_{t=1}^{T}\left(\sum_{i=1}^{N}\left(E_{i t} / A_{i t}\right) / N_{t}\right)}{T} \\
L L P_{i t}=\frac{P_{i t}}{\text { Loans }_{i t}}-\frac{\sum_{t=1}^{T}\left(\sum_{i=1}^{N}\left(P_{i t} / \text { loans }_{i t}\right) / N_{t}\right)}{T}
\end{gathered}
$$

Here, $A_{i t}$ is total assets, $L_{i t}$ is securities and cash due from banks, $E_{i t}$ is total equity, $P_{i t}$ is loan-loss-provisions, and Loans $i t$ is total loans.

The normalization implies that for the equation (1), the mean of the interaction terms is zero and the parameters $\beta_{j}$ are interpreted as the average effect of monetary policy on the growth of loans. The coefficients for the bank characteristic $\left(\rho_{j} ; \mathrm{j}: 1, \ldots, 4\right)$ describe the effect of these characteristics on the growth of loans when the change in short-term money market rates $\left(\Delta i_{m, t}\right.$ and $\left.\Delta i_{m, t-1}\right)$ is zero. The coefficients for the interaction terms $\left(\tau_{j}, \theta_{j}, \mu_{j}, \varphi_{j}\right)$ indicate whether the considered bank characteristic makes any difference in the way the growth in bank lending react to monetary policy changes.

The market concentration is denoted by $M C$. We use the Herfindahl Index (HHI) measured in terms of assets obtained from the European Central Bank. We interact this variable with the monetary policy variables $\left(\Delta i_{m, t}\right.$ and $\left.\Delta i_{m, t-1}\right)$. Mostly, empirical research has found a positive relationship between this interaction variable and credit growth (Adams and Amel, 2005, 2011; Olivero et al., 2011).

The sovereign risk measured as sovereign risk premium is represented by $S R$ : the sovereign bond yield spread of a country relative to Germany ${ }^{7}$. Sovereign bond yield spread has been widely used to measure sovereign risk, because it captures the country credit risk

\footnotetext{
${ }^{7}$ Many previous studies use Germany as a benchmark to calculate sovereign bond yield spreads (Codogno et al., 2003; Bernoth and Wolff, 2008; Bernoth et al., 2012).
} 
(probability of sovereign default) and the country liquidity risk (Codogno et al., 2003; Hallerberg and Wolff, 2008; Gerlach et al., 2010; Favero et al., 2010).

To measure how sovereign risk affects loan supply reaction to monetary policy, we include in model (1) interactions between these variables $\left(\Delta i_{m, t} * S R_{m, t}\right.$ and $\left.\Delta i_{m, t-1} * S R_{m, t}\right)$. In previous sections, we propose that sovereign risk leads to different effects in the monetary policy transmission. Banks that operate in countries with high sovereign risk are more affected by monetary policy tights and might be less affected by monetary policy expansions. To capture this different effect in countries with high sovereign risk, we include in model (1) the square of the interaction variables between the monetary policy indicator and the sovereign risk: $\left(\Delta i_{m, t} * S R_{m, t}\right)^{2}$ and $\left(\Delta i_{m, t-1} * S R_{m, t}\right)^{2}$. If the different effect exists, these squared variables will have a negative coefficient. When the short-term money market rate increases, the decrease in lending associated with a monetary policy contraction will be amplified in countries with high sovereign risk. On the other hand, when the short-term money market rate decreases, the growth in loans associated with a monetary policy expansion will be offset in countries with high sovereign risk $^{8}$.

Country and year effect dummies are included to capture country and year-specific factors. The error term is $\varepsilon_{i, t} ; i=1,2, \ldots, N$ indicates a specific bank $i ; m=1,2, \ldots, M$ indicates a particular country $m ; t=1,2, \ldots, T$ indicates a particular year $t$ and $j$ denotes the number of lags.

Table 2 presents the descriptive statistics of the variables used in the analysis. Table 3 presents the correlations between variables to identify potential collinearity problems between variables. The correlation matrix indicates that the possibility of collinearity between the regressors is small.

\footnotetext{
${ }^{8}$ The introduction of a squared variable to capture asymmetries is used in other areas of research, e.g., market timing in mutual funds (Treynor and Mazuy, 1966).
} 


\section{[Insert tables $2 \& 3]$}

The analysis of the relationship between bank lending and monetary policy proposed in this paper can be affected by endogeneity problems. Monetary policy affects the credit supply of banks, but the situation of the banking sector could affect the monetary decisions as well (Gambacorta and Marques-Ibanez; 2011). To control this problem, the model in equation (1) is estimated using two steps System-GMM (Generalized Method of Moments) with robust errors, which is consistent in the presence of any pattern of heteroskedasticity and autocorrelation. This method allows for controlling the problems of endogeneity and allows us to obtain consistent and unbiased estimates by using lagged independent variables as instruments (Arellano and Bond, 1991). Following Jimborean (2009), the monetary policy indicator and the macroeconomic variables are considered to be exogenous and the bank characteristics and their interactions endogenous. For the endogenous variables, following his estimation strategy, we use second lags as instruments ${ }^{9}$. The exogenous variables are instrumented by themselves.

\subsection{Empirical results}

Table 4 shows the results. In model (a) we introduced the most common bank-specific characteristics used in previous studies: size (SIZE), liquidity $(L I Q)$, and capitalization $(C A P)$. In model (b) we add the variable $L L P$ (loan loss provisions) to control for bank credit risk. In model (c) we add the variable $M C$ (Herfindahl Index) to control for market concentration. In model (d) we estimate the main model without the countries that requested bailouts (Greece, Ireland and Portugal). In model (e) we control for structural breaks.

[Insert table 4]

\footnotetext{
${ }^{9}$ To avoid over-identification problems, deeper lags have been used as instruments for some variables in levels. Based on the difference-in-Hansen tests of exogeneity of instrument subsets, we use credit risk (LLP) and its interactions terms lagged three times and the interactions between SIZE and the monetary policy variables lagged four times.
} 
Regarding significant variables in model (a), the response of bank lending to a monetary policy shock $(\Delta i)$ has the expected negative sign, but only in the current variable. Thus, an increase in the short-term money market rate leads to an immediate reduction of credit supply. Without considering the rest of the variables, a $1 \%$ increase in the current monetary policy indicator leads to a decline in lending of $-0.0716 \%$ for an average bank. However, the effect that the first lag of monetary policy has on lending growth is not significant. The interaction term between SIZE and current and lagged monetary policy variable is positive and significant. Therefore, the lending growth of smaller banks is more sensitive to monetary policy. The interaction term between liquidity (LIQ) and monetary policy is negative and significant. Thus, banks with a higher liquidity ratio are more sensitive to changes in monetary policy. Several previous studies have found a similar result, especially if they analyze European banks (Matousek and Sarantis, 2009; Jimborean, 2009; Bogoev, 2010). Gambacorta and MarquesIbanez (2011) find that highly liquid banks in Europe tend to be more responsive to monetary shocks in periods of crisis. The financial crisis has led European banks to hoard liquidity for reasons of precaution rather than lend it out, which can explain this result. The interaction term between capital (CAP) and current monetary policy has a positive and significant coefficient of 0.0687. This indicates, as previous studies, that poorly capitalized banks reduce lending more than well-capitalized banks during monetary policy tights.

Finally, as we proposed, sovereign risk $(S R)$ is negative and significant with a coefficient of -0.0223 . So, a $1 \%$ increase in the sovereign risk causes a loan decrease of $0.0223 \%$ for an average bank. Therefore, banks that operate in countries with higher risk have fewer opportunities to expand their loan portfolios, because bank funding cost and availability depend on the home country's sovereign risk to an important extent. The quadratic interaction terms between sovereign risk and current monetary policy variable is negative and significant. 
However, as we are interacting two continuous variables (monetary policy and sovereign risk), the marginal effect of monetary policy on the growth of loans will depend on the value of the sovereign risk $(S R)$. To capture this marginal effect we have to take the derivative of equation (1) with respect to monetary policy ${ }^{10}$ :

$$
\frac{\partial \Delta \ln (\text { loans })_{i, t}}{\partial \Delta \mathrm{i}_{m, t}}=\beta_{0}+\tau_{0} S I Z E_{i, t-1}+\theta_{0} L I Q_{i, t-1}+\mu_{0} C A P_{i, t-1}+\gamma_{0} S R_{m, t}+2 \epsilon_{0} \Delta \mathrm{i}_{m, t}\left(S R_{m, t}\right)^{2}
$$

As variables SIZE, $L I Q$, and $C A P$ are normalized with respect to their mean, the marginal effect for an average bank is

$$
\frac{\partial \Delta \ln (\text { loans })_{i, t}}{\partial \Delta \mathrm{i}_{m, t}}=\beta_{0}+\gamma_{0} S R_{m, t}+2 \epsilon_{0} \Delta \mathrm{i}_{m, t}\left(S R_{m, t}\right)^{2}
$$

The marginal effect in equation (3) depends on the monetary policy variable, so we have estimated the marginal effects for an average bank in two different scenarios: a $0.75 \%$ increase and a $0.75 \%$ decrease in the monetary policy indicator (short-term money market rate). We chose this percentage because is the closest multiple of $0.25 \%$ to the mean annual increase/decrease in the short-term money market rate from 1999 to $2012^{11}$. The marginal effect also changes with the level of sovereign risk $(S R)$, so we need to use plots to interpret the results properly.

Figure 1 reports the marginal effect of monetary policy on the growth of loans in relation to risk premium when short-term money market rate increases by $0.75 \%$. The dotted lines represent the $90 \%$ confidence interval ${ }^{12}$. The negative effect of an increase in the short-term money market rate is very low in banks that operate in countries with low risk premium. The

\footnotetext{
${ }^{10}$ Notice that the variables $L L P$ and $M C$ do not appear in equation (2), because they are not included in model (a). ${ }^{11}$ We choose multiples of $0.25 \%$ because many central banks (including the European Central Bank) change their target rates using these multiples. We have also estimated the marginal effect using different increases/decreases in the short-term money market rate. We start from the minimum rate variation in our sample and add $0.25 \%$ to the previous value until we reach the maximum in our sample. The results are similar to a $0.75 \%$ increase/decrease reported in this paper. These results are not included in the article, but are available upon request.

${ }^{12}$ We follow Aiken and West (1991) to compute the confidence intervals.
} 
marginal effect has its minimum when the risk premium is $-0.99 \%$. At this point, a $0.75 \%$ increase in the short-term money market rate only causes a $0.066 \%$ decrease in loans. However, when the risk premium rises the negative effect is bigger. The reduction in credit supply reaches a maximum when the risk premium is $20.91 \%$. At this point, an increase in the money market rate by $0.75 \%$, leads to a $2.61 \%$ reduction in bank loans. Therefore, as we expected, banks that operate in countries with higher risk premiums are more sensitive to monetary policy contractions.

\section{[Insert Fig. 1]}

Figure 2 shows the marginal effect of monetary policy on the growth of loans in relation to risk premium when the short-term money market rate decreases by $0.75 \%$. In this case, we must interpret the marginal effect carefully. As we are assessing the effect of a decrease in the short-term money market rate, if the marginal effect is positive, a decrease in short-term money market rate will have the opposite sign (negative). If the marginal effect is negative, a decrease in the short-term money market rate will have a positive sign. Figure 2 shows that in our sample there is not enough evidence to support any relationship between sovereign risk and loan supply reaction to monetary policy expansions. After the onset of the crisis of 2008, the access of banks to funding is limited and expensive in most euro zone countries, which outweighs the benefits of the reduction in interest rate carried out by the European Central Bank, which could explain this result. In fact, the relationship between monetary policy and the growth of loans is positive and significant when the risk premium is over $13.21 \%$. This means that in countries with high sovereign risk, a decrease in short-term money market rate reduces bank loans, probably because the high default risk and financial restrictions. Only Greece, which asked for a bail out in 2010, has a risk premium over that percentage in $2012^{13}$.

\footnotetext{
${ }^{13}$ To check the robustness of our results, we estimated the model without the countries that requested a bailout. The results, which are presented later in this paper, are similar to the model which includes those countries.
} 


\section{[Insert Fig. 2]}

In Table 4, model (b) we add the variable $L L P$ (loan loss provisions) to control for bank credit risk. The results are similar to those in the model (a). Most of the significant variables in model (a) remain significant except from the interaction term between CAP and current monetary policy changes, which is not significant. The variable SIZE has a positive and significant sign coefficient of 0.0057 , so the size of a bank has a positive but small effect on the lending growth. The variable LLP was not significant and the interaction term between this variable and current monetary policy turns out to be positive and significant. Gambacorta and Marques-Ibanez (2011) argue that in a crisis riskier banks may expand lending by more, especially versus risky segments. Figures 3 and 4 show the marginal effect of monetary policy on the growth of loans in relation to risk premium when the short-term money market rate increases or decreases by $0.75 \%$ respectively ${ }^{14}$. The results are quite similar to those reported in Figs. 1 and 2.

[Insert Figs. 3 \& 4]

In Table 4, model (c) we add the variable $M C$ to control for market concentration. The results are similar to those in the models (a) and (b). All the significant variables in model (b) remain significant except from the variable SIZE. The linear and the quadratic interaction terms between sovereign risk and current monetary policy variable are negative and significant. Moreover, the quadratic interaction term between sovereign risk and lagged monetary policy variable is negative and significant as well. The variable $M C$ is positive and significant with a coefficient of 1.2612 , but the interaction terms between this variable and the monetary policy variable are not significant. As the variable $M C$ is not normalized with respect to their mean, we estimated the marginal effect using the following model:

\footnotetext{
${ }^{14}$ As the variable $L L P$ is normalized with respect to their mean, we follow equation (3) to estimate the marginal effect.
} 
$\frac{\partial \Delta \ln (\text { loans })_{i, t}}{\partial \Delta \mathrm{i}_{m, t}}=\beta_{0}+\gamma_{0} S R_{m, t}+2 \epsilon_{0} \Delta \mathrm{i}_{m, t}\left(S R_{m, t}\right)^{2}+\omega_{0} M C_{m, t}$

To calculate the marginal effect we replaced $M C$ with the median of the countries in the sample. The results show that the marginal effects of monetary policy on the growth of loans in relation to risk premium are similar to those reported previously (see Figs. 5 and 6).We also replaced $M C$ with the mean, the 25 th percentile, and the 75 th percentile, and the results are quite similar ${ }^{15}$.

[Insert Fig. 5 \& 6]

Greece, Ireland, and Portugal requested massive bailouts from the European Union and the International Monetary Fund. To check the robustness of our results, we estimated the main model without them. The results, which are reported in Table 4, model (d), and Figs. 7 and 8, are similar to the models that include those countries.

\section{[Insert Fig. 7 and 8]}

Finally, to control for structural breaks we estimated model $\mathrm{c}$ adding the interaction term between the sovereign risk $(S R)$ and a dummy variable $\mathrm{PC}_{\mathrm{t}}$. This variable takes the value of 1 for the years 1999 to 2007 and of 0 otherwise. It therefore represents the years before the outbreak of the financial crisis. The results, which are reported in Table 4, model (e), and Figs. 9 and 10, are similar to the previous models.

[Insert Fig. 9 and 10]

\section{Conclusions}

Since the onset of the financial crisis of 2008, there was a growing concern about the impact that sovereign risk could have on financial intermediaries, their balance sheets and their ability

\footnotetext{
${ }^{15}$ These results are not shown in the article, but are available upon request.
} 
to grant credit. This paper analyzes how sovereign risk influences bank credit supply reaction to monetary policy through the bank lending channel. The financial crisis showed very clearly that sovereign risk is crucial in how banks can access funds. Greater sovereign risk pushes up the cost and reduces the availability of bank funding. We propose that, due to these financing problems, sovereign risk needs to be carefully considered with other standard bank-specific characteristics when examining the functioning of the BLC of monetary policy. Thus, focusing only on size, liquidity, capitalization, or credit risk is not enough for the accurate assessment of the ability of banks to raise new funds and supply additional loans. Moreover, the effects of sovereign risk on bank lending will be different during easy and tight monetary policies.

Using a sample of European banks from 1999 to 2012, we find that sovereign risk plays an important role in determining loan supply from banks during tight monetary policies. Banks that operate in countries with higher risk premiums are more sensitive to monetary policy contractions, as they reduce lending more. Additionally, we find little evidence to support any relationship between sovereign risk and loan supply reaction to monetary policy expansions.

These results are very interesting for the way monetary policy is conducted in Europe. They suggest that the single monetary policy that has existed in Europe since 1999 is not affecting all the countries equally during tight monetary policies. Thus, the European Central Bank should take into account the sovereign risk differences between countries. Several steps can be taken to ensure a smooth transmission of monetary policy and guarantee that the loan supply meets the economy's needs. First of all, the banking system should be strengthened by increasing the capital of banks. Secondly, a European banking union would help reduce the ties between sovereign risk and bank funding. Finally, countries with excessive deficit should get their finances under control, which will reduce sovereign spreads. 
This paper has tried to shed light on the effect of sovereign risk on BLC. However, further analysis is needed to fully understand the role of sovereign risk and country differences in the monetary policy transmission mechanism.

\section{Acknowledgements}

The authors would like to thank the University of Cantabria Foundation for Education and Research in the Financial Sector (UCEIF Foundation) and the Chair on Place Branding of the University of Cantabria for financial support. 


\section{References}

Acharya, V.V., Shin, H.S. and Yorulmazer, T. (2011): Crisis resolution and bank liquidity. Review of Financial studies, 24 (6), 2166-2205.

Adams, R.M. and Amel, D.F. (2005): The effects of local banking market structure on the bank lending channel of monetary policy. Finance and Economics Discussion Series 2005-16, Board of Governors of the Federal Reserve System.

Adams, R.M. and Amel, D.F. (2011): Market structure and the pass-through of the federal funds rate. Journal of Banking and Finance, 35 (5), 1087-1096.

Adelino, M. and Ferreira, M.A. (2014): Sovereign Rating Downgrades and Bank Lending Supply. SSRN. http://ssrn.com/abstract=2376721

Aiken, L.S. and West, S.G. (1991): Multiple regression: Testing and interpreting interactions. Sage Publications, Incorporated.

Albertazzi, U., Ropele, T., Sene, G. and Signoretti, F. (2012): The impact of the sovereign debt crisis on the activity of Italian banks. Bank of Italy Occasional Papers, (133).

Allen, W.A. and Moessner, R. (2012): The liquidity consequences of the euro area sovereign debt crisis. BIS Working Papers, (No. 390).

Alter, A. and Schüler, Y.S. (2012): Credit spread interdependencies of European states and banks during the financial crisis. Journal of Banking \& Finance, 36 (12), 3444-3468.

Altunbas, Y., Fazylov, O. and Molyneux, P. (2002): Evidence on the bank lending channel in Europe. Journal of Banking and Finance, 26 (11), 2093-2110.

Altunbas, Y., Gambacorta, L. and Marques-Ibanez, D. (2009): Securitisation and the bank lending channel. European Economic Review, 53 (8), 996-1009. 
Altunbas, Y., Gambacorta, L. and Marques-Ibanez, D. (2010): Bank risk and monetary policy. Journal of Financial Stability, 6 (3), 121-129.

Angeloni, I., Kashyap, A. and Mojon, B. (2003): Monetary policy transmission in the Euro area, Cambridge University Press, Cambridge.

Arellano, M. and Bond, S. (1991): Some tests of specification for panel data: Monte Carlo evidence and an application to employment equations. Review of Economic Studies, 58 (2), 277-297.

Arena, M., Reinhart, C. and Vazquez, F. (2007): The lending channel in emerging economies: Are foreign banks different? IMF Working Paper, (No. 07/48).

Barth, J.R., Prabha, A.P. and Yun, G. (2012): The Eurozone financial crisis: Role of interdependencies between bank and sovereign risk. Journal of Financial Economic Policy, 4 (1), 76-97.

Beltratti, A. and R. M. Stulz (2009): Why did some banks perform better during the credit crisis? A cross-country study of the impact of governance and regulation. Charles A Dice Center Working Paper No. 2009-12.

Bernanke, B.S. (2007): The financial accelerator and the credit channel. In Remarks at a Conference at the Federal Reserve Bank of Atlanta.

Bernanke, B.S. and Blinder, A.S. (1988): Credit, money and aggregate demand. The American Economic Review, 78 (2), 435-439.

Bernanke, B.S. and Gertler, M. (1995): Inside the black box: the credit channel of monetary policy transmission. Journal of Economic Perspectives, 9 (4), 27-48.

Bernoth, K. and Wolff, G.B. (2008): Fool the markets? Creative accounting, fiscal transparency and sovereign risk premia. Scottish Journal of Political Economy, 55 (4), 465-487. 
Bernoth, K., Von Hagen, J. and Schuknecht, L. (2012): Sovereign risk premiums in the European government bond market. Journal of International Money and Finance, 31 (5), 975-995.

Bofondi, M., Carpinelli, L. and Sette, E. (2012): Credit supply during a sovereign crisis. Bank of Italy Working Paper, No. 909.

Bogoev, J. (2010): Banks' risk preferences and their impact on the loan supply function: Empirical investigation for the case of the Republic of Macedonia. Privredna kretanja $i$ ekonomska politika, 20 (124), 63-109.

Boivin, J., Kiley, M.T. and Mishkin, F.S. (2010): How has the monetary transmission evolved over time? National Bureau of Economic Research, (No. w15879).

Borensztein, E., Cowan, K. and Valenzuela, P. (2006): The sovereign ceiling lite and bank credit ratings in emerging markets economies. Banco Central de Chile and Washington, D.C. Mimeo.

Brei, M., Gambacorta, L. and von Peter, G. (2013): Rescue packages and bank lending. Journal of Banking \& Finance, 37. 490-505

Breton, R., Pinto, C. and Weber, P.F. (2012): Banks, moral hazard and public debts. Fsr Financial, 57.

Brissimis, S.N. and Delis, M.D. (2009): Identification of a loan supply function: A crosscountry test for the existence of a bank lending channel. Journal of International Financial Markets, Institutions and Money, 19 (2), 321-335.

Brunnermeier, M.K. and Oehmke, M. (2012): Bubbles, financial crises and systemic risk. National Bureau of Economic Research, (No. w18398). 
Bruyckere, V., Gerhardt, M., Schepens, G. and Vander Vennet, R. (2012): Bank/sovereign risk spillovers in the European debt crisis. National Bank of Belgium Working Paper, (No. 232).

Caceres, C., Guzzo, V. and Segoviano, M. (2010): Sovereign Spreads: Global risk aversion, contagion or fundamentals? International Monetary Fund Working Paper 10/120.

Caruana, J. and Avdjiev, S. (2012): Sovereign creditworthiness and financial stability: an international perspective. Banque de France Financial Stability Review, (16), 71-85.

CGFS (2011): "The impact of sovereign credit risk on bank funding conditions". CGFS Papers, (No. 43), July 2011.

Ciccarelli, M., Maddaloni, A. and Peydro, J.L. (2013): Heterogeneous transmission mechanism: Monetary policy and financial fragility in the Euro area. European Central Bank Working Paper Series, (No. 1527).

Codogno, L., Favero, C. and Missale, A. (2003): Yield spreads on EMU Government Bonds. Economic Policy, 18 (37), 503-532.

Correa, R., Lee, H., Sapriza, H. and Suárez, G. (2012): Sovereign credit risk, banks’' government support, and bank stock returns around the world. Board of Governors of the Federal Reserve System. International Finance Discussion Papers, (No. 1069).

Davies, M. and Ng, T. (2011): The rise of sovereign credit risk: implications for financial stability. BIS Quarterly Review, 59-70.

De Bondt, G.J. (1999): Banks and monetary transmission in Europe: empirical evidence. Banca Nazionale del Lavoro Quarterly Review, 52 (209), 149-168.

Dell'Ariccia, G., Laeven, L. and Suarez, G. (2013): Bank Leverage and Monetary Policy's RiskTaking Channel: Evidence from the United States. IMF Working Paper. WP/13/143. 
Disyatat, P. (2011): The bank lending channel revisited. Journal of Money, Credit and Banking, 43 (4), 711-734.

Ehrmann, M., Gambacorta, L., Martínez-Pagés, J., Sevestre, P. and Worms, A. (2003): Financial systems and the role of banks in monetary policy transmission in the Euro Area. In: Angeloni, I., Kashyap, A., Mojon, B. (Eds.), Monetary policy transmission in the Euro Area. Cambridge University Press, Cambridge, 235-269.

European Central Bank (2012): Financial integration in Europe. European Central Bank, Eurosystem, April 2012.

Favero, C.A., Giavazzi, F. and Flabbi, L. (1999): The transmission mechanism of monetary policy in Europe: evidence from banks' balance sheets. National Bureau of Economic Research, (No. w7231).

Favero, C.A., Pagano, M. and Von Thadenn, E.L. (2010): How does liquidity affect government bond yields? Journal of Financial and Quantitative Analysis, 45, 107-134.

Ferri, G., Liu, L.G. and Majnoni, G. (2001): The role of rating agency assessments in less developed countries: Impact of the proposed Basel guidelines. Journal of Banking and Finance, 25 (1), 115-148.

Freixas, X., Giannini, G., Hoggarth, G. and Soussa, F. (1999): Lender of the last resort: A review of the literature. Financial Stability Review, 7, 151-167.

Gambacorta, L. (2005): Inside the bank lending channel. European Economic Review, 49 (7), 1737-1759.

Gambacorta, L. and Marques-Ibanez, D. (2011): The bank lending channel: lessons from the crisis. Economic Policy, 26 (66), 135-182. 
Gambacorta, L. and P.E. Mistrulli (2004): Does bank capital affect lending behavior?. Journal of Financial Intermediation, 13(4), 436-57.

Gerlach, S., Schulz, A. and Wolff, G. (2010): Banking and sovereign risk in the euro area. CEPR Discussion Paper, (No. DP 7833).

Gibson, M.S. (1997): The bank lending channel of monetary policy transmission: evidence from a model of bank behavior that incorporates long-term customer relationships. Board of Governors of the Federal Reserve System. International Finance Discussion Papers, (No. 584).

Grande, G., Levy, A., Panetta, F. and Zaghini, A. (2011): Public guarantees on bank bonds: effectiveness and distortions. OECD Financial Market Trends, 2011/2.

Gray, D.F. and Malone, S.W. (2012): Sovereign and financial-sector risk: measurement and interactions. Annual Review of Financial Economics, 4 (1), 297-312.

Hallerberg, M. and Wolff, G.B. (2008): Fiscal institutions, fiscal policy and sovereign risk premia in EMU. Public Choice, 136 (3-4), 379-396.

Hosono, K. (2006): The transmission mechanism of monetary policy in Japan: evidence from banks' balance sheets. The Journal of Japanese and International Economies, 20 (3), 380405.

Ioannidou, V.P., Ongena, S., and Peydro, J.L. (2009): Monetary Policy, Risk- Taking, and Pricing: Evidence from a Quasi-Natural Experiment. CentER Discussion Paper No. 2009-31S.

Isakova, A. (2008): Monetary policy efficiency in the economies of Central Asia. Czech Journal of Economics and Finance (Finance a uver), 58 (11-12), 525-553. 
Jimborean, R. (2009): The role of banks in the monetary policy transmission in the new EU member states. Economic Systems, 33 (4), 360-375.

Jimenez, G., Ongena, S., Peydro, J.L. and Saurina, J. (2008): Hazardous Times for Monetary Policy: What Do Twenty-Three Million Bank Loans Say About the Effects of Monetary Policy on Credit Risk-Taking?. Banco de España documento de Trabajo 0833.

Kakes, J. and Sturm, J.E. (2002): Monetary policy and bank lending: Evidence from German banking groups. Journal of Banking and Finance, 26 (11), 2077-2092.

Kashyap, A.K., and Stein, J.C. (1995a): The impact of monetary policy on bank balance sheets. Carnegie-Rochester Conference Series on Public Policy, 42, 151-195.

Kashyap, A.K. and Stein, J.C. (1995b): The role of banks in the transmission of monetary policy. NBER Reporter, Fall, National Bureau of Economic Research.

Kashyap, A.K., and Stein, J.C. (2000): "What do a million observations on banks say about the transmission of monetary policy? The American Economic Review, 90 (3), 407-428.

Kashyap, A.K., Stein, J.C. and Wilcox, D.W. (1993): Monetary policy and credit conditions: Evidence from the composition of external finance. American Economic Review, 83, 7898.

Kishan, R.P. and Opiela, T.P. (2000): Bank size, bank capital and the bank lending channel. Journal of Money, Credit and Banking, 32 (1), 121-141.

Kishan, R.P. and Opiela, T.P. (2006): Bank capital and loan asymmetry in the transmission of monetary policy. Journal of Banking and Finance, 30 (1), 259-285.

Maddaloni, A., and Peydro, J.L. (2011): Bank Risk-Taking, Securitization, Supervision and Low Interest Rates: Evidence from the Euro Area and U.S. Lending Standards. Review of Financial Studies, 24(6), 2121-165. 
Matousek, R. and Sarantis, N. (2009): The bank lending channel and monetary transmission in Central and Eastern European Countries. Journal of Comparative Economics, 37 (2), 321 334.

Mishkin, F.S. (1995): Symposium on the monetary transmission mechanism. The Journal of Economic Perspectives, 9 (4), 3-10.

Olivero, M.P., Li, Y. and Jeon, B.N. (2011): Consolidation in banking and the lending channel: Evidence from bank-level data in Asia and Latin America. Journal of International Money and Finance, 30 (6) 1034-1054.

Opiela T. (2008): Differential deposit guarantees and the effect of monetary policy on bank lending. Economic Inquiry, 46 (4) 610-623.

Paligorova, T., and Santos, J.A.C. (2012): Monetary Policy and Bank Risk-Taking: Evidence from the Corporate Loan Market. Working paper, Federal Reserve Bank of New York.

Peek, J. and Rosengren, E.S. (1995): Bank lending and the transmission of monetary policy. In Conference series-Federal Reserve Bank of Boston. Federal Reserve Bank of Boston, 4768.

Peter, M. and Grandes, M. (2005): How important is sovereign risk in determining corporate default premia? The case of South Africa. International Monetary Fund.

Popov, A. and van Horen, N. (2013): The impact of sovereign debt exposure on bank lending: Evidence from the European debt crisis. ECB mimeo.

Pruteanu-Podpiera, A.M. (2007): The role of banks in the Czech monetary policy transmission mechanism. Economics of Transition, 15 (2), 393-428.

Romer, C.D. and Romer, D.H. (1990): New evidence on the monetary transmission mechanism. Brookings Papers on Economic Activity, 1990 (1), 149-213. 
Said, F.F. (2013): The dynamic of bank lending channel: Basel regulatory constraint. Economic Modelling, 31, 606-613.

Schich, S. and Lindh, S. (2012): Implicit Guarantees for bank debt: Where do we stand? OECD Financial Market Trends, 2012/1.

Steudler, O. and Zurlinden, M. (1998): Monetary policy, aggregate demand and the lending behavior of bank groups in Switzerland. In BIS Conference Papers, 6, 279-293.

Treynor, J. and Mazuy, K. (1966): Can mutual funds outguess the market? Harvard Business Review, 44 (4), 131-136.

Trichet, J.C. (2010): The ECB's response to the recent tensions in financial markets. In $38^{\text {th }}$ Economic Conference of the Österreichische Nationalbank, Vienna, 31.

Unsal, D.F. and Caceres, C. (2011): Sovereign spreads and contagion risks in Asia. International Monetary Fund, 11.

Vause, N. and von Peter, G. (2011): Euro area sovereign crisis drives global financial markets. BIS Quarterly Review, December, 1-14.

Walsh, C.E. (2003): Monetary theory and policy. $2^{\text {nd }}$ ed. Cambridge, MA: MIT Press.

Wu, J., Luca, A.C. and Jeon, B.N. (2011): Foreign bank penetration and the lending channel in emerging economies: Evidence from bank-level panel data. Journal of International Money and Finance, 30 (6), 1128-1156.

Zawadowski, A. (2011): Interwoven lending, uncertainty and liquidity hoarding. Boston U. School of Management Research Paper, (No 2011-13).

Zoli, M.E. (2013): Italian sovereign spreads: their determinants and pass-through to bank funding costs and lending conditions, (13-84). International Monetary Fund. 
TABLE 1: SAMPLE

PANEL A: NUMBER OF BANKS PER COUNTRY

\begin{tabular}{|c|c|c|c|c|c|c|c|c|c|c|c|c|c|c|c|}
\hline & & & \multicolumn{8}{|c|}{ Number of observations } & \multicolumn{5}{|c|}{ Number of banks } \\
\hline \multicolumn{3}{|c|}{ Austria } & \multicolumn{8}{|c|}{2,240} & \multicolumn{5}{|c|}{235} \\
\hline \multicolumn{3}{|c|}{ Belgium } & \multicolumn{8}{|c|}{334} & \multicolumn{5}{|c|}{44} \\
\hline \multicolumn{3}{|c|}{ Finland } & \multicolumn{8}{|c|}{44} & \multicolumn{5}{|c|}{8} \\
\hline \multicolumn{3}{|c|}{ France } & \multicolumn{8}{|c|}{1,848} & \multicolumn{5}{|c|}{235} \\
\hline \multicolumn{3}{|c|}{ Germany } & \multicolumn{8}{|c|}{18,906} & \multicolumn{5}{|c|}{1,781} \\
\hline \multicolumn{3}{|c|}{ Greece } & \multicolumn{8}{|c|}{100} & \multicolumn{5}{|c|}{17} \\
\hline \multicolumn{3}{|c|}{ Ireland } & \multicolumn{8}{|c|}{76} & \multicolumn{5}{|c|}{13} \\
\hline \multicolumn{3}{|c|}{ Italy } & \multicolumn{8}{|c|}{3,067} & \multicolumn{5}{|c|}{540} \\
\hline \multicolumn{3}{|c|}{ Luxembourg } & \multicolumn{8}{|c|}{548} & \multicolumn{5}{|c|}{72} \\
\hline \multicolumn{3}{|c|}{ Netherlands } & \multicolumn{8}{|c|}{188} & \multicolumn{5}{|c|}{32} \\
\hline \multicolumn{3}{|c|}{ Portugal } & & & & 13 & & & & & & & 24 & & \\
\hline & Spain & & & & & 67 & & & & & & & 124 & & \\
\hline & Total & & & & & 28,1 & 161 & & & & & & 3,125 & & \\
\hline PANEL & B: TEM & IPORA & RY D & ISTRIY & BUTIO & N OF T & THE S & AMPLE & & & & & & & \\
\hline & 1999 & 2000 & 2001 & 2002 & 2003 & 2004 & 2005 & 2006 & 2007 & 2008 & 2009 & 2010 & 2011 & 2012 & $\begin{array}{l}\text { Total } \\
\text { Obs. }\end{array}$ \\
\hline $\begin{array}{c}\text { N. of } \\
\text { banks }\end{array}$ & 1,425 & 1,584 & 1,654 & 1,725 & 1,660 & 1,635 & 1,638 & 1,778 & 2,614 & 2,622 & 2,615 & 2,543 & 2,466 & 2,202 & 28,161 \\
\hline
\end{tabular}

TABLE 2: SAMPLE STATISTICS

\begin{tabular}{|c|c|c|c|c|}
\hline Variable & Mean & Standard deviation & Minimum & Maximum \\
\hline$\Delta \ln ($ loans $)$ & 0.0303 & 0.1894 & -6.2336 & 1.3654 \\
$\Delta \ln (\mathrm{GDP})$ & 0.0340 & 0.0875 & -0.1670 & 0.2780 \\
$\Delta \mathrm{i}$ & -0.2429 & 1.2481 & -3.4059 & 1.4418 \\
$\mathrm{SIZE}$ & 13.6465 & 1.6631 & 7.6091 & 21.6704 \\
$\mathrm{LIQ}$ & 0.2415 & 0.1342 & 0.0000 & 0.9502 \\
$\mathrm{CAP}$ & 0.0869 & 0.0584 & 0.0008 & 0.9704 \\
$\mathrm{LLP}$ & 0.0315 & 0.8236 & -30.0456 & 52.0208 \\
$\mathrm{SR}$ & 0.2826 & 0.8917 & -1.1954 & 21.0025 \\
$\mathrm{MC}$ & 0.0323 & 0.0291 & 0.0140 & 0.3700 \\
\hline
\end{tabular}

The statistics of the variables SIZE, LIQ, CAP, LLP are calculated before the normalization to show more comprehensive information. 
TABLE 3: CORRELATIONS

\begin{tabular}{|c|rrrrrrrr|}
\hline & $\Delta \ln (\mathrm{GDP})$ & \multicolumn{1}{c}{$\Delta \mathrm{i}$} & \multicolumn{1}{c}{ SIZE } & LIQ & CAP & LLP & SR & MC \\
\hline$\Delta \ln (\mathrm{GDP})$ & 1 & & & & & & & \\
$\Delta \mathrm{i}$ & 0.3831 & 1 & & & & & & \\
$\mathrm{SIZE}$ & -0.0067 & -0.0172 & 1 & & & & & \\
LIQ & -0.0050 & 0.0283 & -0.0104 & 1 & & & & \\
$\mathrm{CAP}$ & -0.0082 & -0.0196 & -0.1707 & -0.0485 & 1 & & & \\
$\mathrm{LLP}$ & 0.0048 & -0.0010 & -0.0413 & 0.1233 & 0.2212 & 1 & & \\
SR & -0.1898 & -0.0716 & 0.0799 & -0.1267 & 0.2136 & -0.0093 & 1 & \\
$\mathrm{MC}$ & 0.0121 & -0.0130 & 0.2724 & -0.0889 & 0.1501 & -0.0162 & 0.2572 & 1 \\
\hline
\end{tabular}


TABLE 4: RESULTS

\begin{tabular}{|c|c|c|c|c|c|c|c|c|}
\hline & \multicolumn{2}{|l|}{ (a) } & (b) & (c) & \multicolumn{2}{|l|}{ (d) } & \multicolumn{2}{|l|}{ (e) } \\
\hline$\Delta \ln (\text { loans })_{\mathrm{t}-1}$ & $0.1992(1.35)$ & & $-0.0932(-0.66)$ & $-0.0915(-0.64)$ & $0.0163(0.16)$ & & $-0.0835(-0.59)$ & \\
\hline$\Delta \ln (\mathrm{GDP})_{\mathrm{t}}$ & $0.4355(1.04)$ & & $0.3132(0.96)$ & $0.0700(0.20)$ & $-0.0243(-0.03)$ & & $0.4063(1.00)$ & \\
\hline$\Delta \ln (\mathrm{GDP})_{\mathrm{t}-1}$ & $0.1027(0.28)$ & & $0.3156(0.84)$ & $-0.0001(0.00)$ & $-0.9623(-1.61)$ & & $0.3558(0.72)$ & \\
\hline$\Delta \mathrm{i}_{\mathrm{t}}$ & $-0.0716(-1.83) *$ & & $-0.0606(-1.98) * *$ & $-0.0624(-2.11) * *$ & $-0.1779(-1.67) *$ & & $-0.0733(-2.43)$ & $* *$ \\
\hline$\Delta \mathbf{i}_{\mathrm{t}-1}$ & $0.0032(0.15)$ & & $-0.0133(-0.76)$ & $-0.0141(-0.81)$ & $-0.0756(-1.79)$ * & $*$ & $-0.0169(-0.98)$ & \\
\hline SIZE $_{t-1}$ & $0.0018(0.68)$ & & $0.0057(2.11) \quad * *$ & $0.0031(1.13)$ & $0.0015(0.86)$ & & $0.0034(1.23)$ & \\
\hline $\mathrm{LIQ}_{\mathrm{t}-1}$ & $0.0166(0.72)$ & & $-0.0119(-0.37)$ & $-0.0035(-0.11)$ & $-0.0340(-1.13)$ & & $-0.0111(-0.33)$ & \\
\hline $\mathrm{CAP}_{\mathrm{t}-1}$ & $-0.0403(-0.56)$ & & $-0.1066(-0.86)$ & $-0.1264(-1.01)$ & $-0.0293(-0.28)$ & & $-0.1363(-1.14)$ & \\
\hline $\operatorname{LLP}_{\mathrm{t}-1}$ & & & $0.0006(0.25)$ & $0.0006(0.28)$ & $0.0058(1.66)$ & $*$ & $0.0009(0.41)$ & \\
\hline$\Delta \mathrm{i}_{\mathrm{t}} * \mathrm{SIZE}_{\mathrm{t}-1}$ & $0.0023(5.35)$ & $* * *$ & $0.0022(5.55) \quad * * *$ & $0.0019(4.13) \quad * * *$ & $0.0000(0.02)$ & & $0.0019(4.03)$ & $* * *$ \\
\hline$\Delta \mathrm{i}_{\mathrm{t}-1} * \mathrm{SIZE}_{\mathrm{t}-1}$ & $0.0009(1.87) *$ & & $0.0012(2.90) \quad * * *$ & $0.0013(3.45) \quad * * *$ & $0.0009(2.24)$ & $* *$ & $0.0012(3.18)$ & \\
\hline$\Delta \mathrm{i}_{\mathrm{t}} * \mathrm{LIQ}_{\mathrm{t}-1}$ & $-0.0161(-2.06) *$ & $* *$ & $-0.0197(-2.37) * *$ & $-0.0173(-2.01) * *$ & $-0.0148(-1.24)$ & & $-0.0200(-2.32)$ & $* *$ \\
\hline$\Delta \mathrm{i}_{\mathrm{t}-1} * \operatorname{LIQ}_{\mathrm{t}-1}$ & $0.0040(0.57)$ & & $-0.0023(-0.3)$ & $-0.0028(-0.37)$ & $-0.0039(-0.45)$ & & $-0.0045(-0.61)$ & \\
\hline$\Delta \mathrm{i}_{\mathrm{t}} * \mathrm{CAP}_{\mathrm{t}-1}$ & $0.0687(2.16) *$ & $* *$ & $0.0369(0.92)$ & $0.0239(0.68)$ & $-0.0373(-0.97)$ & & $0.0271(0.75)$ & \\
\hline$\Delta \mathrm{i}_{\mathrm{t}-1} * \mathrm{CAP}_{\mathrm{t}-1}$ & $0.0088(0.32)$ & & $0.0195(0.52)$ & $0.0287(0.78)$ & $0.0330(1.08)$ & & $0.0323(0.86)$ & \\
\hline$\Delta \mathrm{i}_{\mathrm{t}}^{*} \operatorname{LLP}_{\mathrm{t}-1}$ & & & $0.0035(1.82) *$ & $0.0039(2.14) \quad * *$ & $0.0084(4.29)$ * & $* * *$ & $0.0039(2.10)$ & \\
\hline$\Delta \mathrm{i}_{\mathrm{t}-1} * \mathrm{LLP}_{\mathrm{t}-1}$ & & & $-0.0002(-0.24)$ & $-0.0003(-0.41)$ & $0.0008(0.51)$ & & $-0.0004(-0.48)$ & \\
\hline $\mathrm{MC}_{\mathrm{t}}$ & & & & $1.2612(1.96) \quad * *$ & $1.6919(2.92)$ & $* * *$ & $1.1936(1.83)$ & \\
\hline$\Delta \mathrm{i}_{\mathrm{t}} * \mathrm{MC}_{\mathrm{t}}$ & & & & $0.0710(1.21)$ & $0.3911(2.26)$ * & $* *$ & $0.0839(1.50)$ & \\
\hline$\Delta \mathrm{i}_{\mathrm{t}-1} * \mathrm{MC}_{\mathrm{t}}$ & & & & $-0.0734(-1.30)$ & $0.0346(0.70)$ & & $-0.0584(-1.01)$ & \\
\hline $\mathrm{SR}_{\mathrm{t}}$ & $-0.0223(-1.90) *$ & & $-0.0285(-2.85) * * *$ & $-0.0213(-2.52) * *$ & $-0.0280(-2.00) *$ & $* *$ & $-0.0150(-1.71)$ & \\
\hline $\mathrm{SR}_{\mathrm{t}} * \mathrm{PC}_{\mathrm{t}}$ & & & & & & & $-0.1167(-2.08)$ & \\
\hline$\Delta \mathrm{i}_{\mathrm{t}} * \mathrm{SR}_{\mathrm{t}}$ & $-0.0106(-1.57)$ & & $-0.0085(-1.26)$ & $-0.0114(-1.80) *$ & $-0.0308(-1.84) *$ & & $-0.0109(-1.72)$ & \\
\hline$\Delta \mathrm{i}_{\mathrm{t}-1} * \mathrm{SR}_{\mathrm{t}}$ & $0.0034(0.83)$ & & $0.0045(1.21)$ & $0.0009(0.22)$ & $-0.0072(-0.73)$ & & $-0.0004(-0.10)$ & \\
\hline$\left(\Delta \mathrm{i}_{\mathrm{t}} * \mathrm{SR}_{\mathrm{t}}\right)^{2}$ & $-0.0035(-1.78) *$ & & $-0.0033(-1.73) *$ & $-0.0034(-1.93) *$ & $-0.0111(-2.22)$ * & $* *$ & $-0.0033(-1.83)$ & \\
\hline$\left(\Delta \mathrm{i}_{\mathrm{t}-1} * \mathrm{SR}_{\mathrm{t}}\right)^{2}$ & $-0.0007(-1.41)$ & & $-0.0007(-1.34)$ & $-0.0009(-1.90) *$ & $-0.0037(-1.12)$ & & $-0.0009(-1.96)$ & \\
\hline CONS & $-0.1145(-3.44) *$ & $* * *$ & $-0.0657(-2.42) * *$ & $-0.1019(-4.10) * * *$ & $-0.2082(-3.85)$ * & $* * *$ & $-0.1014(-4.31)$ & $* * *$ \\
\hline Country dummies & Yes & & Yes & Yes & Yes & & Yes & \\
\hline Year dummies & Yes & & Yes & Yes & Yes & & Yes & \\
\hline Linear test & & & & & & & $-0.1316(-2.43)$ & \\
\hline $\mathrm{m}_{2}$ & 0.152 & & 0.701 & 0.671 & 0.773 & & 0.719 & \\
\hline Hansen & 0.126 & & 0.143 & 0.138 & 0.311 & & 0.183 & \\
\hline
\end{tabular}

Coefficients associated with each variable. In brackets, T-student; $* * *$ indicates a level of significance of $0.01, * *$ indicates a level of significance of 0.05 , * indicates a level of significance of $0.1 ; \mathrm{m}_{2}$ is the p-value of the $2 \mathrm{nd}$ order serial correlation statistic. Linear test is the linear restriction test of the sum of the coefficients associated with $\mathrm{SR}_{\mathrm{t}}$ and $\mathrm{SR}_{\mathrm{t}} * \mathrm{PC}_{\mathrm{t}}$. Hansen is the $\mathrm{p}$-value of the over-identifying restriction test. 


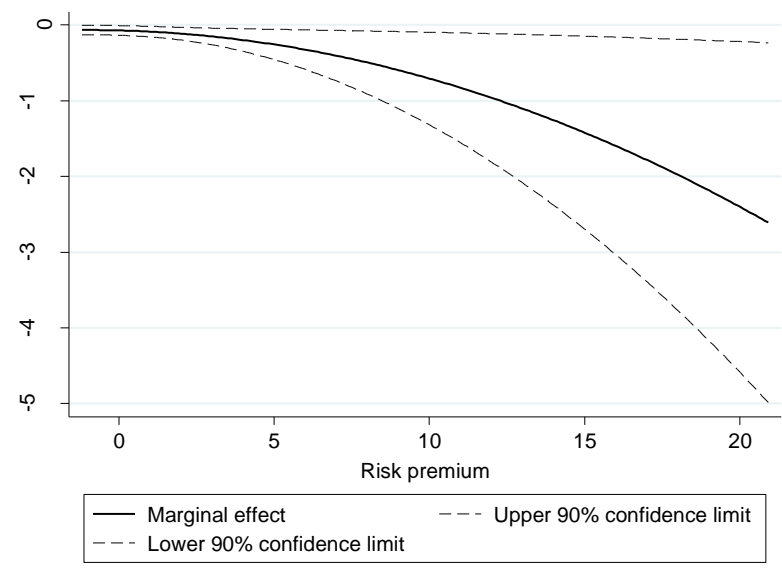

Fig. 1. Marginal effect of monetary policy on the growth of loans in relation to risk premium when short-term money market rate increases by $0.75 \%$. Based on model (a), Table 4.

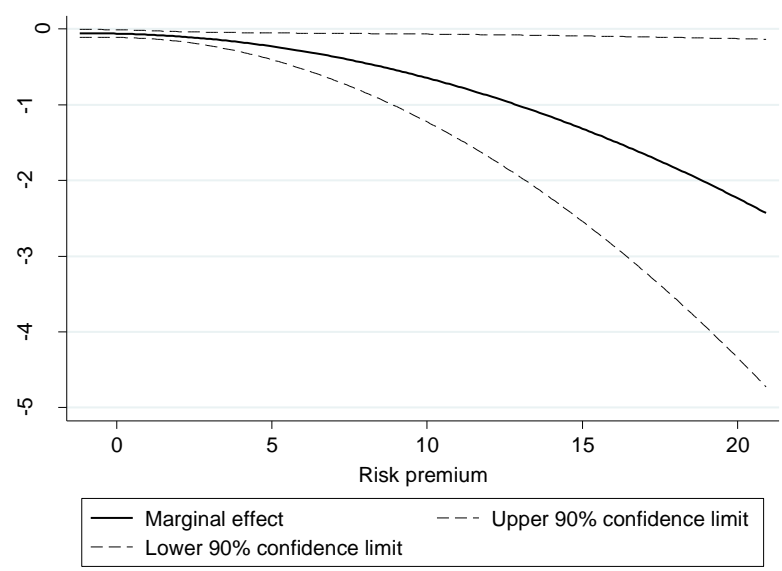

Fig. 3. Marginal effect of monetary policy on the growth of loans in relation to risk premium when shortterm money market rate increases by $0.75 \%$. Based on model (b), Table 4.

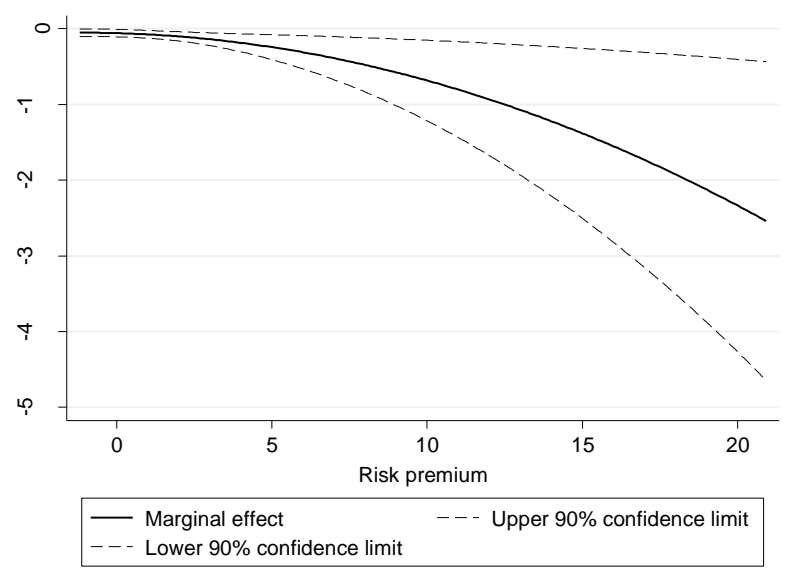

Fig. 5. Marginal effect of monetary policy on the growth of loans in relation to risk premium when shortterm money market rate increases by $0.75 \%$. Based on model (c), Table 4.

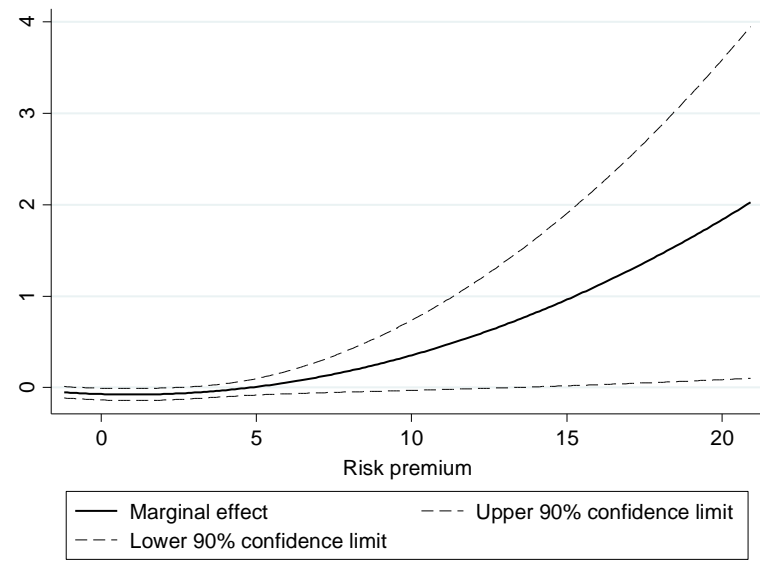

Fig. 2. Marginal effect of monetary policy on the growth of loans in relation to risk premium when shortterm money market rate decreases by $0.75 \%$. Based on model (a), Table 4.

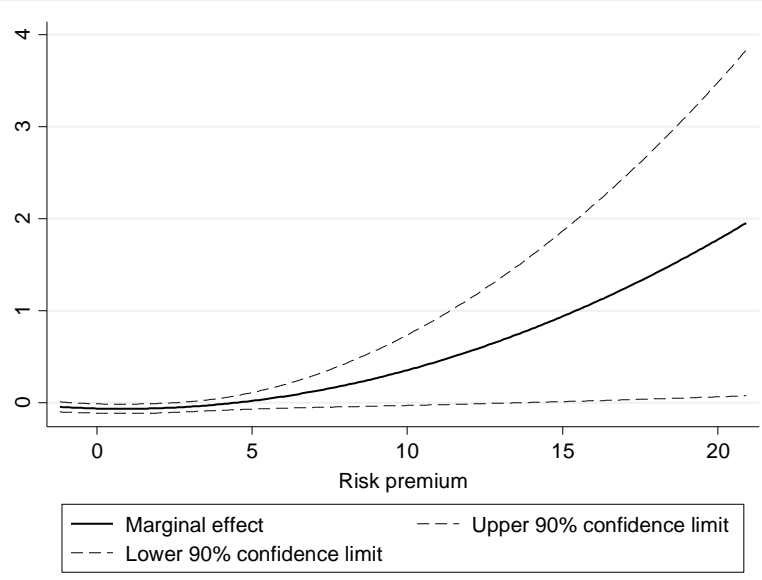

Fig. 4. Marginal effect of monetary policy on the growth of loans in relation to risk premium when shortterm money market rate decreases by $0.75 \%$. Based on model (b), Table 4.

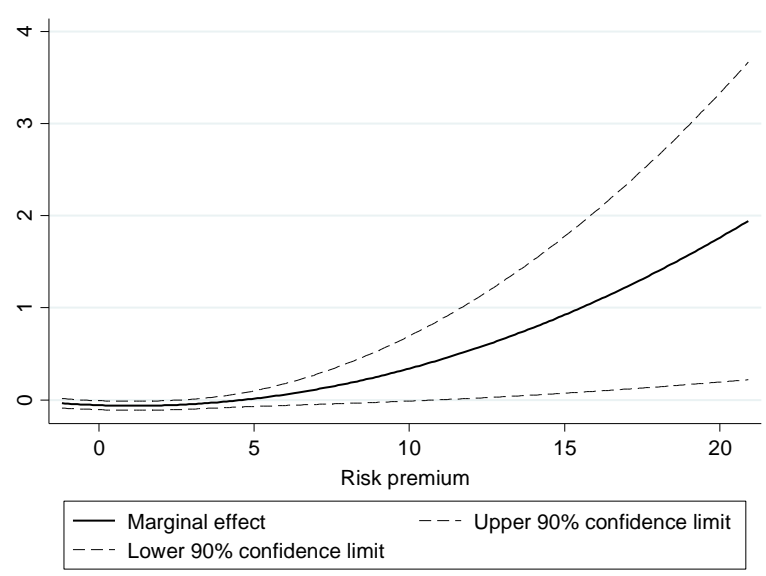

Fig. 6. Marginal effect of monetary policy on the growth of loans in relation to risk premium when shortterm money market rate decreases by $0.75 \%$. Based on model (c), Table 4. 


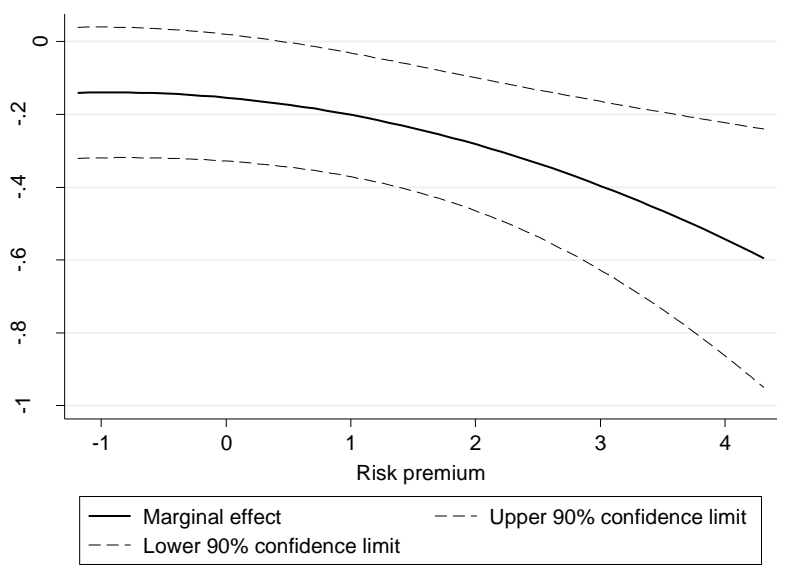

Fig. 7. Marginal effect of monetary policy on the growth of loans in relation to risk premium when shortterm money market rate increases by $0.75 \%$. Based on model (d), Table 4. Without Greece, Ireland and Portugal.

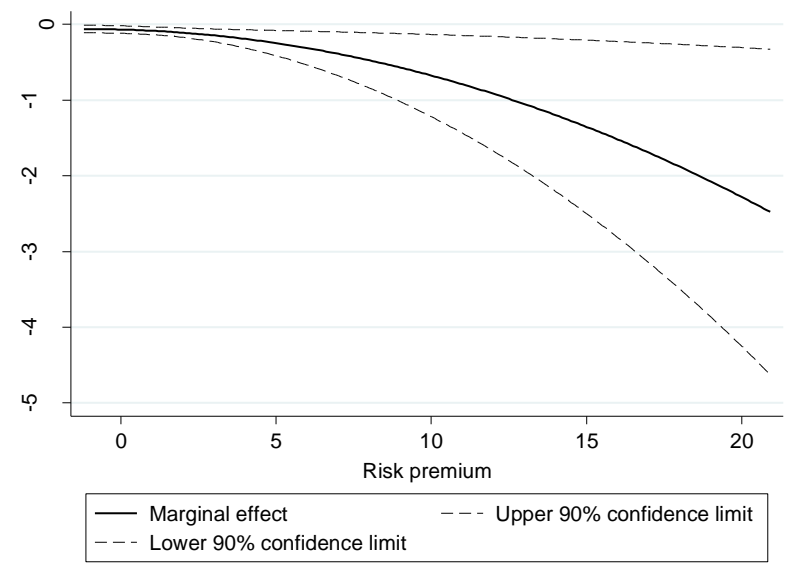

Fig. 9. Marginal effect of monetary policy on the growth of loans in relation to risk premium when shortterm money market rate increases by $0.75 \%$. Based on model (e), Table 4.

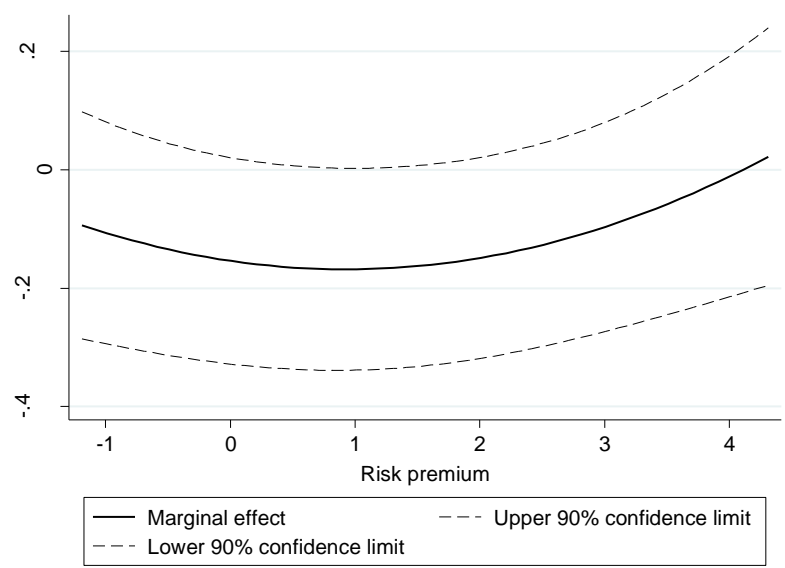

Fig. 8. Marginal effect of monetary policy on the growth of loans in relation to risk premium when shortterm money market rate decreases by $0.75 \%$. Based on model (d), Table 4. Without Greece, Ireland and Portugal.

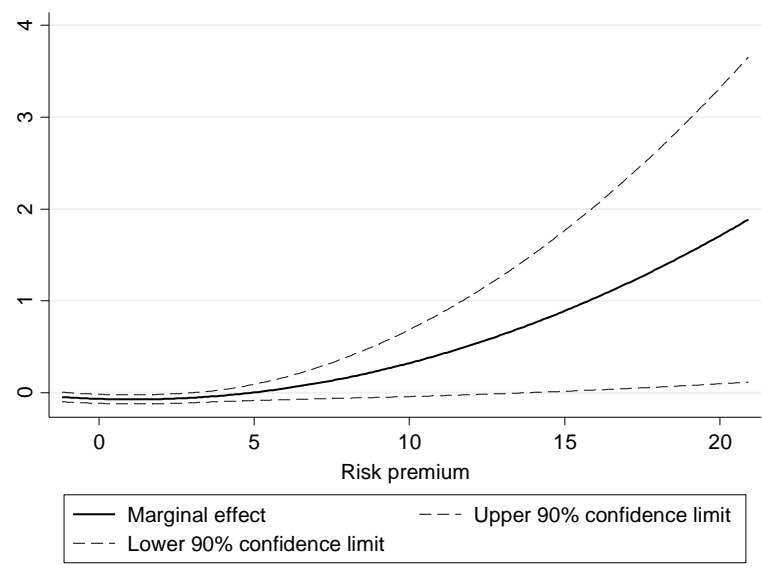

Fig. 10. Marginal effect of monetary policy on the growth of loans in relation to risk premium when shortterm money market rate decreases by $0.75 \%$. Based on model (e), Table 4. 